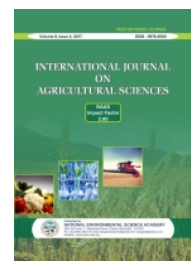

\title{
UTILIZATION OF BREADFRUIT AS GLUTEN-FREE FLOUR PRODUCT
}

\author{
Alminda Magbalot-Fernandez ${ }^{1 *}$, Saikat Kumar Basu' ${ }^{2}$ Hewage Perera ${ }^{1}$, \\ Losan Madar ${ }^{1}$ and Lutgarda Palomar ${ }^{1}$ \\ ${ }^{1}$ School of Agriculture and Food Technology, University of the South Pacific, \\ Alafua, Apia, Samoa; ${ }^{2}$ PS Lethbridge, AB Canada T1J 4B3
}

Received: 15.05.2020

Revised: 22.05.2020

Accepted: 10.06.2020

\begin{abstract}
Along with recent health challenges, there is a need to develop more convenient, nutritious, ready-to-eat and tasty breadfruit products to increase available food source and minimize postharvest losses. Hence, this study was conducted at the Food Technology laboratory of the University of the South Pacific, Alafua campus to evaluate healthy product innovations from indigenous crops of the Pacific Island Countries which include breadfruit. The different gluten-free breadfruit flour products developed at the Food Technology laboratory, University of the South Pacific, Alafua campus, Apia, Samoa were breadfruit cookies, breadfruit cake and breadfruit polvoron (powdered candy). The breadfruit flour was analyzed for proximate contents and its products were tested for acceptability of taste using a nine hedonic rating scale. Proximate analysis of the breadfruit flour revealed a higher protein (6.56\%), ash (4.78\%) and crude fat (1.84\%) but lower DM (85.29\%) and crude fibre (4.10\%) contents than fresh crushed breadfruit. Sensory tests revealed that thirteen percent $(13 \%)$ of the 30 panels disliked $(<5)$ the breadfruit cookies and polvoron (powdered candy) while eighty-seven percent $(87 \%)$ rated the products as acceptable $(<5)$ based on a nine-point hedonic rating scale. Moreover, seventeen percent $(17 \%)$ disliked $(<5)$ the breadfruit cake and eighty-three percent $(83 \%)$ liked $(>5)$ the product based on a ninepoint hedonic rating scale. These showed that these gluten-free breadfruit flour products are nutritious and tasty with great potential for commercialization.
\end{abstract}

Keywords: Product Development, Gluten-Free, Breadfruit, Flour, Sensory Test, Value-Added Product.

\section{INTRODUCTION}

Breadfruit (Artocarpus altilis) is a large tropical flowering tree that produces 100-600 edible fruits per year (NTBG, 2016b). It has been a traditional staple crop to almost all islanders around Oceania where it was originally domesticated over 3,000 years ago (Ragone, 1997; 2011). Its cultivation covers in more than 90 countries around the tropics (Ragone, 2016; Ragone \& Cavaletto, 2006). Breadfruit is an excellent source of calories for the diet. Aside from carbohydrates, it contains fiber, vitamin C, potassium, protein and phytochemicals such as flavonoids (Graham \& Bravo, 1981; Jones et al., 2011; Liu et al., 2015; Loos et al., 1981; Ragone \& Cavaletto, 2006; Turi, et al., 2015; Ijarotimi \& Aroge, 2005).
It is significantly valued as gluten free (Ijarotimi \& Aroge, 2005; Jones et al., 2011) since gluten intolerance is a growing epidemic in the U.S. and has increasing incidence worldwide (Green \& Celler, 2007). Gluten is a protein composite found in wheat and related grains, including barley and rye. Gluten provides elasticity to dough, to rise, keep shape and give the final product a chewy texture making it an important characteristic of a wheat flour (Adebowale, et al., 2004; Agboola, et al., 1990; Akanbi, et al., 2009; Akanbi, et al., 2011). Breadfruit has the potential to be used for a wide range of food applications for local use and export. It can be consumed boiled, baked, roasted, pickled, steamed or fried (Graham \& Bravo, 1981; Jones et al., 2011; Jones et al., 2011). However, it has short shelf-life as fruit ripens in 1 to 3 days followed by rapid starch deterioration after a week. Soft and over-ripened

*Corresponding author: almindafernandez5@gmail.com 
breadfruits are undesirable for consumption which leads to substantial loss. Cold storage can prolong shelf life and firmness for only a few more weeks (Maharaj \& Sankat, 1989; Worrell et al., 2002).

It is also processed to starch (Loos et al., 1981), flour (Nochera \& Caldwell, 1992; Arcelay \& Graham, 1984; Loos et al., 1981; Graham \& Bravo, 1981; Olatunji \& Akerele, 1978) and value-added products like chips, fries, dips, baked goods, desserts, and beverages (Ragone \& Cavaletto, 2006). The breadfruit flour has also been developed as pasta product (Nochera \& Ragone, 2019), breadfruit bar (Nochera \& Ragone, 2016), Noodles, Manchuria, Phulka and Halwa (Ravinder et al., 2018). Breadfruit flours have high water absorption capacity indicating more hydrophilic components which can potentially be used as a thickener in viscous foods such as soups, sauces, and puddings, and in certain bakery products (Chen, 2016).

Breadfruit flour products continue to expand and complement existing and potential markets for the fresh or processed fruit. Various researchers, farmers, cooperatives, and entrepreneurs in Hawaii, Samoa and American Samoa, the Caribbean, Central America, and West Africa have started the breadfruit flour industry producing small quantities of flour for local use and for export (Ragone \& Cavaletto, 2006). With the emerging health challenges, there is a need to develop more convenient, nutritious, ready-to-eat breadfruit products of acceptable taste to increase available food source and minimize postharvest losses. Hence, this study was conducted at the Food Technology laboratory of the University of the South Pacific, Alafua campus to innovate nutritious products from indigenous crops of the Pacific Island Countries such as breadfruit.

\section{MATERIALS AND METHODS}

The native breadfruit 'Momolega' cultivar in Samoa was utilized for the development of the breadfruit value-added products. Mature breadfruit was harvested by hand from trees in USP, Alafua campus, Apia, Samoa on October 2017. Washed breadfruit was peeled, and the pulp was sectioned and dried at $60 \circ \mathrm{C}$ for $24 \mathrm{~h}$. Dried pulp was ground in a grinder to produce flour that passed through an 80 mesh $(180 \mu \mathrm{m})$ sieve. The different gluten-free breadfruit flour products developed at the Food Technology laboratory, University of the South Pacific, Alafua campus, Apia, Samoa were breadfruit cookies, breadfruit cake and breadfruit polvoron (powdered candy). All ingredients (sugar, baking powder, egg, cinnamon, milk, butter) were purchased commercially except for breadfruit flour and water. The ingredients were manually mixed thoroughly and stirred continuously to obtain a homogenous mixture. The cookie batter was molded into circular shapes on a cookie sheet and baked at $180^{\circ} \mathrm{C}$ for 10 min. The cake batter poured in a baking pan was baked immediately at $200^{\circ} \mathrm{C}$ for 30 minutes. The polvoron (powdered candy) batter was molded into circular shapes on a sheet and packed individually. Proximate analyses (moisture, ash, protein, crude fat, crude fiber) were determined for the breadfruit flour and fresh breadfruit crushed according to procedures outlined by AOAC (2005). The samples were analyzed at the Central laboratory, USP, Alafua, Apia, Samoa. The breadfruit flour products were tested for acceptability of taste using a nine hedonic rating scale according to Larmond (1992) and Meeilgard et al., (2006). The product was evaluated by 30 untrained panelists. A nine-point verbal category hedonic scale was used: 1 , dislike extremely; 2 , dislike very much; 3 , dislike moderately; 4 , dislike slightly; 5 , neither like nor dislike; 6 , like slightly; 7 , like moderately; 8 , like very much; and 9, like extremely. The scale was presented as a line numbered 1-9 with the beginning, middle, and end parameters specified. The products were presented without additives. Data obtained from the taste panel were analyzed using the $\mathrm{z}$ test for comparison.

\section{RESULTS AND DISCUSSION}

The proximate analysis of the breadfruit flour and fresh crushed breadfruit (Table 1) showed that breadfruit flour has higher protein $(6.56 \%)$, ash $(4.78 \%)$ and crude fat $(1.84 \%)$ than fresh crushed breadfruit $(2.63 \%$ protein, $1.35 \%$ ash, $1.37 \%$ crude fat). While the DM (85.29\%) and crude fibre $(4.10 \%)$ of breadfruit flour decreased from 89.26\% DM and $4.12 \%$ crude fiber of fresh crushed breadfruit. The sensory evaluation for breadfruit flour products namely, breadfruit cookies, breadfruit cake and breadfruit polvoron (powdered candy) are presented in Figure 1-3. Among the 30 panels, thirteen percent (13\%) disliked the breadfruit cookies, defined as a score of 1-4 on a nine-point hedonic rating scale while eighty-seven percent $(87 \%)$ liked the product. Liking the product was defined as a score of 6-9 on a nine-point hedonic rating scale. A hypothesized population mean of 6 resulted for one-tailed probability value of a $\mathrm{z}$ test $(0.011221886)$ for the given data which is significantly lower than $5 \%$.

In the case of breadfruit cake, seventeen percent (17\%) disliked $(<5)$ and eighty-three percent $(83 \%)$ liked $(>5)$ the product based on a nine-point hedonic rating scale. A hypothesized population mean of 6 resulted for one-tailed probability value of a $\mathrm{z}$ test $(0.013310273)$ for the given data which is significantly lower than $5 \%$. Moreover, thirteen percent $(13 \%)$ of the panels disliked $(<5)$ the breadfruit polvoron (powdered candy) while eighty-seven 
Table 1: Proximate analysis (DM\%, ash, protein, crude fat, crude fiber) of the breadfruit flour and fresh breadfruit crushed.

\begin{tabular}{|l|c|c|c|c|c|c|}
\hline Sample & $\begin{array}{c}\text { DM \% } \\
\text { (Fresh sample) }\end{array}$ & $\begin{array}{c}\text { DM \% } \\
\text { (Dried sample) }\end{array}$ & Ash \% & Protein \% & $\begin{array}{c}\text { Crude } \\
\text { Fat\% }\end{array}$ & $\begin{array}{c}\text { Crude } \\
\text { Fibre \% }\end{array}$ \\
\hline $\begin{array}{l}\text { Breadfruit } \\
\text { flour }\end{array}$ & & 85.29 & 4.78 & 6.56 & 1.84 & 4.10 \\
\hline $\begin{array}{l}\text { Breadfruit } \\
\text { (crushed) }\end{array}$ & 63.47 & 89.26 & 1.35 & 2.63 & 1.37 & 4.12 \\
\hline
\end{tabular}

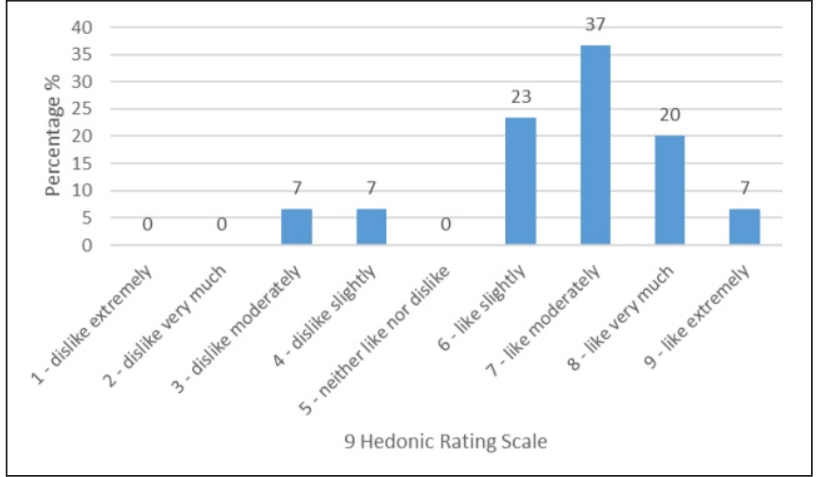

Figure 1: Overall Acceptability of Taste in Breadfruit Cookies.

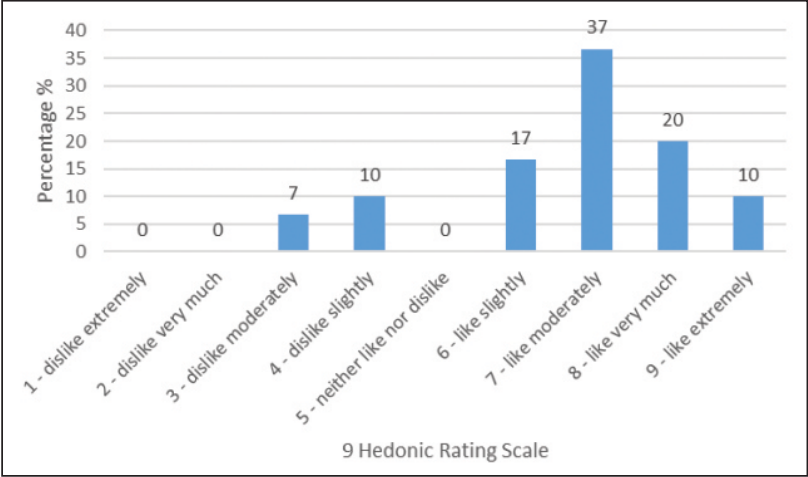

Figure 2: Overall Acceptability of Taste in Breadfruit Cake.

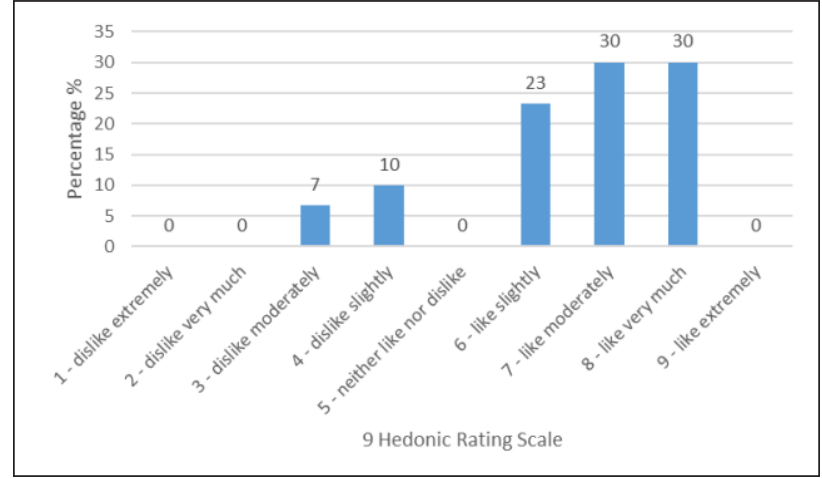

Figure 3: Overall Acceptability of Taste in Breadfruit Polvoron (Powdered Candy).

percent $(87 \%)$ rated the product as acceptable $(<5)$ based on a nine-point hedonic rating scale. A hypothesized population mean of 6 resulted for one-tailed probability value of a $\mathrm{z}$ test $(0.011221886)$ for the given data which is significantly lower than $5 \%$.

Results of the study showed that the breadfruit flour has higher protein $(6.56 \%)$, ash $(4.78 \%)$ and crude fat $(1.84 \%)$ but lower DM (85.29\%) and crude fibre (4.10\%) than fresh crushed breadfruit. This conforms that breadfruit is an excellent source of calories from carbohydrates and contains fiber, vitamin $\mathrm{C}$, potassium, protein and phytochemicals such as flavonoids (Graham \& Bravo, 1981; Jones et al., 2011; Liu et al., 2015; Loos et al., 1981; Ragone \& Cavaletto, 2006; Turi, et al., 2015; Ijarotimi \& Aroge, 2005). In addition, breadfruit pasta product is high in carbohydrates (73.3/100 g), contains fiber (9.3/100g), protein $(2.32 \mathrm{~g} / 100)$, Vit. D, calcium, iron, potassium and low in fat $(8.33 / 100 \mathrm{~g})$ as reported by Nochera \& Ragone (2019). While breadfruit bar is also high in carbohydrates (83.92g/100), contains dietary fiber (3.8 g/100), crude fibre (1.97\%/100g), protein (2.05g/100), Vit. A, C, calcium, iron and low in fat (Nochera \& Ragone, 2016). Noodles, Manchuria, Phulka and Halwa from breadfruit flour have 
likewise superior proximate compositions (Ravinder et al., 2018).

Sensory tests revealed that thirteen percent (13\%) of the 30 panels disliked $(<5)$ the breadfruit cookies and polvoron (powdered candy) while eighty-seven percent (87\%) rated the product as acceptable $(<5)$ based on a nine-point hedonic rating scale. While in breadfruit cake, seventeen percent $(17 \%)$ disliked $(<5)$ and eighty-three percent $(83 \%)$ liked $(>5)$ the product based on a nine-point hedonic rating scale. In another study, sensory evaluation indicates that $80.3 \%$ of the panelists $(n=71)$ found the breadfruit flour pasta as acceptable while 18.3\% disliked the pasta (Nochera \& Ragone, 2019). Similarly, sensory evaluation of a breadfruit bar indicates that $81 \%$ of the panelists found the bar acceptable while 19\% disliked the bar (Nochera \& Ragone, 2016). Breadfruit flour processed into Noodles, Manchuria, Phulka and Halwa also have superior sensory attributes (Ravinder et al., 2018). Proximate analysis showed that breadfruit flour has higher protein (6.56\%), ash $(4.78 \%)$ and crude fat $(1.84 \%)$ than fresh crushed breadfruit. Though, the DM (85.29\%) and crude fibre (4.10\%) of breadfruit flour decreased.

This is evident that the different gluten-free breadfruit flour products developed at USP such as breadfruit cookies, cake and polvoron are not only nutritious but also acceptable by taste. Hence, these gluten-free breadfruit flour value-added products have great potential for commercialization as healthy alternatives.

\section{ACKNOWLEDGEMENTS}

The authors are grateful for the funding support of the School of Agriculture and Food Technology, University of the South Pacific, Alafua campus, Apia, Samoa.

\section{REFERENCES}

1. Chen, A.H. 2016. Characterization of Functional Properties of Breadfruit Flour. Thesis. University of Hawaii. https://scholarspace.manoa.hawaii.edu/ bitstream/10125/51551/2016-12-ms-chenalfred. pdf, Retrieved 2019.

2. Graham, H.D. \& de Bravo, E.N. 1981. Composition of the breadfruit. J. Food Sci., 46, 535-539.

3. Green, P.H.R. \& Cellier, C. 2007. Celiac Disease. $N$ Engl J Med 357: 1731- 1743.

4. Ijarotimi, S.O. \& Aroge, F. 2005. Evaluation of the nutritional composition, sensory, and physical properties of a potential weaning food from locally available food materials-breadfruit (Artocarpus altilis) and soybean (Glycene max). Pol. J. Food Nutr. Sci., 14, 411-415. 7.

5. Jones, A.M.P., Lane, W.A., Murch, S.J., Ragone, D. \& Cole, I.B. 2011. Breadfruit: An old crop with a new future. In Comprehensive Biotechnology, 2nd ed.; Moo-Young, M., Ed.; Elsevier B.V.: Amsterdam, The Netherlands, Chapter: 4.18; pp. 235-239.

6. Jones, A.M.P., Ragone, D., Aiona, K., Lane, W.A. \& Murch, S.J. 2011. Nutritional and morphological diversity of breadfruit (Artocarpus, Moraceae): Identification of elite cultivars for food security. $J$. Food Comp. Anal., 24, 1091-1102.

7. Larmond, E. 1992. Laboratory Methods for Sensory Evaluation of Food; Research Branch, Publication No. 1864; Agriculture Canada: Ottawa, ON, Canada.

8. Liu, Y., Ragone, D. \& Murch, S. 2015. Breadfruit (Artocarpus altilis): A source of high-quality protein for food security and novel food products. Amino Acids, 47, 84.

9. Loos, P.J., Hood, L.F. \& Graham, H.D. 1981. Isolation and characterization of starch from breadfruit. Cereal Chem., 58, 282-286.

10. Maharaj, R. \& Sankat, C. 1989. The shelf-life of breadfruit stored under ambient and refrigerated conditions. Symposium on Tropical Fruit in International Trade. 269, 411-424.

11. Meilgaard, M.C., Thomas Carr, B. \& Van Civille, G. 2006. Sensory Evaluation Techniques; CRC Press: Boca Raton, FL, USA

12. National Tropical Botanical Garden (NTBG). 2016b. Hunger Initiative [Online]. Breadfruit Institute. http://ntbg.org/breadfruit/hunger.php Retrieved 2019.

13. Nochera, CL. \& Ragone, D. 2016. Preparation of a Breadfruit Flour Bar. Foods 2016, 5, 37; doi:10.3390/foods5020037.

14. Nochera, CL. \& Ragone, D. 2019. Development of a Breadfruit Flour Pasta Product. Foods 2019, 8, 110; doi:10.3390/foods8030110.

15. AOAC. 2005. Official Methods of Analysis of AOAC International, 18th ed.; Method 2005, 08; AOAC International: Gaithersburg, MD, USA

16. Olatunji, O. \& Akerele, A.J. 1978. Comparative rheological properties and bread qualities of wheat flour diluted with tropical tuber and Breadfruit flour. Journal of Cereal Chemistry. 55: 1-6. 
17. Ragone, D. 2016. Breadfruit for food and nutritional security in the 21st century. Trop. Agric., Tropical Agriculture (Trinidad) Special Issue. 18-29.

18. Ragone, D. \& Cavaletto, C. 2006. Sensory evaluation of fruit quality and nutritional composition of 20 breadfruits (Artocarpu, Moraceae) cultivars. Econ. Bot., 60, 335-346.

19. Ravinder, A., Waghray, K., Subbarao, \& Evangeline, S.J. 2018. Studies on Production of Gluten Free Products from Breadfruit Flour. J Food Nutr Popul Health. Vol.2 No.1:8.
20. Turi, C.E., Liu, Y., Ragone, D. \& Murch, S.J. 2015. Breadfruit (Artocarpus altilis and hybrids): A traditional crop with the potential to prevent hunger and mitigate diabetes in Oceania. Trends Food Sci. Tech., 45, 264-272.

21. Worrell, D.B., Carrington, C.S. \& Huber, D.J. 2002. The use of low temperature and coatings to maintain storage quality of breadfruit, Artocarpus altilis (Parks.) Fosb. Postharvest biology and technology, 25 (1): 33-40. 